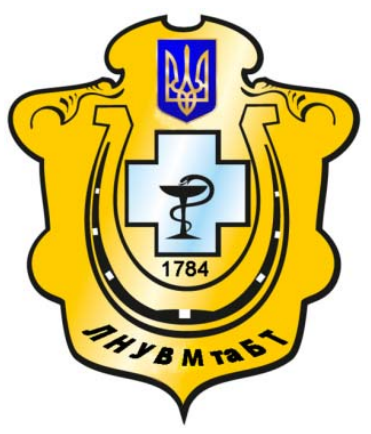

Науковий вісник Львівського національного університету ветеринарної медицини та біотехнологій імені С.3. Гжицького

Scientific Messenger of Lviv National University of Veterinary Medicine and Biotechnologies named after S.Z. Gzhytskyj

doi:10.15421/nvlvet6637

ISSN 2413-5550 print

ISSN 2518-1327 online

$\underline{\text { http://nvlvet.com.ua/ }}$

УДК 619:638.15-08

\title{
Токсикологічна оцінка препарату «Біоконтакт плюс» для медоносної бджоли
}

\author{
С.Ф. Тушак, Т.О. Романишина \\ tushak.svetlana@mail.ru, tatjana.romanishina@yandex.ua \\ Житомирський начіональний агроекологічний університет, \\ вул. Корольова, 39, м. Житомир, 10025, Україна
}

\begin{abstract}
Стаття присвячена встановленню токсикологічної очінки дезінфектанта нового покоління «Біоконтакт плюс» для бджіл методом визначення контактної та оральної токсичності. Досліди проводили лабораторно на базі Житомирського наиіонального агроекологічного університету, факультету ветеринарної медицини, кафедри мікробіології, фармакологї̈ та епізоотології. Визначення контактної та оральної токсичності проводили методом групової обробки бджіл у ентомофільних садках та ізоляторах. Тривалість періоду спостереження: для гострої фази - 48 год, для хронічної- 20 діб. Було встановлено, що за контактного використання спостерігається тимчасовий токсичний ефект за концентрації 0,3\%. При визначення шллункової токсичності - ефект гострої токсичності спостерігали за концентрачії 0,3\%. При використанні препарату в конщентраціях 0,1\% та 0,15\% виявили стимулюючу та активізуючи дію препарату. За низьких конщентрацій (0,03\%, 0,01\%) позитивних змін у життєдіяльності бджіл не відмічали. Можливість використання препарату бджолам методом підгодівлі у концентраціях 0,1\% та 0,15\% у якості стимулятора необхідно вивчати по змінам фізіологічних показників (цитологічний та морфологічний склад гемолімфи, розвиток жирового тіла), оціниі дї на господарсько-корисні показники сімей, змінам санітарно-гігієнічної поведінки бджіл.
\end{abstract}

Ключові слова.Медоносні бджоли, Біоконтакт плюс,гостра та хронічна токсичність,травленний екран, ізолятор, ентомологічний садок, дезінфектант, біостимулятор, заразні хвороби бджіл.

\section{Токсикологическая оценка препарата «Биоконтакт плюс» для медоносной пчелы}

\author{
С.Ф. Тушак, Т.А. Романишина \\ tushak.svetlana@mail.ru, tatjana.romanishina@yandex.ua \\ Житомирский начиональный агроэкологический университет, \\ ул. Королева, 39, г. Житомир, 10025, Украина
}

\begin{abstract}
Статья посвящена установлению токсикологической оценки дезинфектанта нового поколения «Биоконтакт плюс» для пчел методом определения контактной и оральной токсичности. Опыты проводили лабораторно на базе Житомирского национального агроэкологического университета, факультета ветеринарной медицины, кафедры микробиологии, фармакологии и эпизоотологии. Определение контактной и оральной токсичности проводили методом групповой обработки пчел в энтомофильных садах и изоляторах. Продолжительность периода наблюдения: для острой фазы - 48 ч, для хронической - 20 суток. Было установлено, что законтактного использования наблюдается временный токсический эффект при концентрации 0,3\%. При определении желудочной токсичности - эффект острой токсичности наблюдали при концентрации 0,3\%. При использовании препарата в кониентращиях 0,1\% и 0,15\% обнаружили стимулирующее и активизирующее действие препарата. При низких концентраций $(0,03 \%, 0,01 \%)$ положительных изменений в жизнедеятельности пчел не отмечали. Возможность использования препарата пчелам методом подкормки в концентрачиях 0,1\% и 0,15\% в качестве стимулятора необходимо изучать по изменениям физиологических показателей (иитологический и морфологический состав
\end{abstract}

\section{Citation:}

Tushak, S.F., Romanishina, T.O. 2016). Toxicological estimation of the drug «Biocontact plus» for honeybees. Scientific Messenger LNUVMBT named after S.Z. Gzhytskyj, 18, 2(66), 185-188. 
гемолимфы, развитие жирового тела), оценке воздействия на хозяйственно-полезные показатели семей, изменениям санитарно-гигиенического поведения пчел.

Ключевые слова. Медоносные пчель, Биоконтакт плюс, острая и хроническая токсичность, травленный экран, изолятор, энтомологический сад, дезинфектант, биостимулятор, заразные болезни пчел.

\title{
Toxicological estimation of the drug «Biocontact plus» for honeybees
}

\author{
S.F. Tushak, T.O. Romanishina \\ tushak.svetlana@mail.ru, tatjana.romanishina@yandex.ua \\ Zhytomyr National Agroecological University, \\ Korolova Str., 39, Zhytomyr, 10025, Ukraine
}

The article is devoted to the toxicological estimation of the disinfectant of new generation "Biocontact plus» for bees using the method of contact and oral toxicity definition. The experiments were carried out at the laboratory of Zhytomyr National Agroecological University at the faculty of Veterinary Medicine, Department of Microbiology, Pharmacology and Epizootology. Definition of contact and oral toxicity was carried out by the method of bees' group treatment in entomophilic gardens and isolators. The duration of the observation period: for acute phase - 48 hour, for chronic phase - 20 days. It was concluded, that the contact use of the drug results in temporary effect, if concentration is $0.3 \%$. While estimating the toxicity in the stomach, the effect of acute toxicity was observed at the level of concentration $0.3 \%$. If the drug is used with the concentration $0.1 \%$ and $0.15 \%$, is has stimulating and activating effect. If the level of concentration is low $(0.03 \%, 0.01 \%)$, no positive changes in the vital functions of the bees were observed. The possibility of use the drug in the function of stimulator for bees using the method of nutrition additives with the level of concentration $0.1 \%$ and $0.15 \%$ was proved.It is necessary to study the possibility of the usage of the drug in the function of stimulator for bees using the method of nutrition additives with the level of concentration $0.1 \%$ and $0.15 \%$ taking into consideration the changes of physiological markers (cytological and morphological hemolymph composition, development of lipid droplet), assessment of influence on the economically useful markers of families, changes in sanitary and hygiene behaviour of bees.

Key words: Honeybees, Biocontact plus, acute and chronic toxicity, digestive screen, isolator, entomological garden, desifectant, biostimulants, contagious diseases of bees

\section{Вступ}

За останні роки сільське господарство України, зокрема така галузь як бджільництво має стрімкий розвиток. Однією із причин, що згубно впливає на розвиток бджільництва в Україні залишаються інфекційні хвороби бджіл (Meged' and Polishhuk, 1990; Galatjuk, 2010). Ринок ветеринарних біостимуляторів та дезінфектантів переповнений препаратами, що попереджують виникнення заразних хвороб бджіл, але неконтрольоване використання лікувальних засобів викликає появу резистентних форм збудників хвороб, що порушують власні захисні механізми бджіл, призводять до появи бджіл-мутантів, змінюють мікрофлору кишечнику бджіл, псують продукцію бджільництва. Наразі, на ветеринарному ринку з'являються нові маловивчені препарати для профілактики хвороб медоносних бджіл, що потребують вивчення токсичних властивостей та вивчення оптимальних доз використання задля профілактики заразних хвороб (Abbot, 1925). «Біоконтакт плюс» принципово новий ефективний дезінфектант, що проявляє антимікробну дію на грамнегативну та грампозитивну мікрофлору,віруцидну дію, антипротозойну, фунгіцидну і діє на дріжджі. Препарат широко використовують для проведення профілактичної, вимушеної вологої та аерозольної дезінфекції тваринницьких та птахівничих приміщень та інших об'єктів ветеринарного призначення.

Даних по дослідженню препарату «Біоконтакт плюс» щодо гострої та хронічної токсичності для бджіл не встановлено.

Мета досліджень. Вивчення гострого та хронічного рівня токсичності препарату «Біоконтакт плюс» при використанні контактного та орального методів за боротьби 3 заразними хворобами бджіл. Визначення можливості використання препарату у якості стимулятора у певних концентраціях.

\section{Матеріал і методи досліджень}

Визначення ступеня небезпеки і токсичності препарату «Біоконтакт плюс» для бджіл проводили за загальноприйнятою методикою випробовування чутливості бджіл до отрутохімікатів (Osinceva, 2000). Дослідження виконували в лабораторії кафедри мікробіології, фармакології та епізоотології Житомирського національного агроекологічного університету впродовж квітня-червня 2016 р. Визначення оральної та контактної токсичності досліджуваного препарату проводили в лабораторних умовах методами групової обробки. Тривалість періоду спостереження: для гострої фази - 48 год, для хронічної фази - 20 діб. Дослідні зразки утримували у термостаті з системою пасивної вентиляції, де підтримували температуру $26^{\circ} \mathrm{C}$ та відносну вологість $35-70 \%$.

Для визначення контактної дії препарату використовували метод травленного екрану (Gar, 1963), коли внутрішню поверхню банки обробляли спиртом 3 метою створення матової знежиреної поверхні, потім за допомогою ручного пульвелізатора внутрішню стінку ізолятора обробляли розчином дезінфектанту виробничої концентрації. Коли з поверхні зникали краплі (30-40 хв) в кожен ізолятор підсаджували 30 бджіл. Ізолятори обробляли розчинами у таких концентраціях: $0,3 \% ; 0,1 \% ; 0,15 \%$ та $0,01 \%$.

Для визначення шлункової токсичності дії інсектециду використовували принцип згодовування 
об'єктам отруєного корму. Для цього бджіл поміщали до ентомофільного садочка по 30 особин і з 50\% цукровим сиропом згодовували препарат 3 певними визначеними концентраціями $(0,3 \% ; 0,1 \% ; 0,15 \%$; $0,03 \% ; 0,01 \%)$.

Облік загиблих комах проводили кожні 12 год.

\section{Результати та їх обговорення}

При дослідженні контактної дії препарату ми виявили тимчасову токсичну дію на бджіл. Так, при концентрації препарату 0,3\% на 4-й день дослідження бджоли в ізоляторі стали неактивними, збивалися в кучку (рис.1).

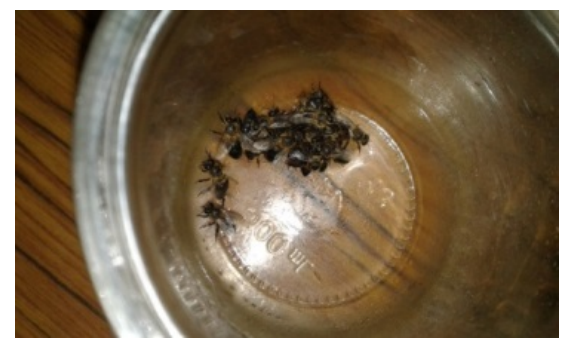

Рис.1. Токсична дія препарату у ізоляторі за концентрації 0,3\%
Після чого через дві доби відійшло 25\% бджіл. У ізоляторах 3 концентраціями $0,1 \% ; 0,15 \%$ та $0,01 \%$ бджоли активні, без видимих ознак негативної дії препарату. На 21 добу дослідження в кожному з ізоляторів відійшло по 25\% бджіл.

Результати прояву токсичної дії препарату «Біоконтакт плюс» в залежності від концетрації в 50\%-ному цукровому сиропі представлені в таблиці 1.

Аналіз даних наведених в таблиці 1 показує, що гостру токсичність при згодовуванні для бджіл виявив препарат 3 концентрацією у цукровому сиропі 0,3\%. За чотири доби досліду, період гострої токсичності, ми відмічали відхід 10\% бджіл. На 7-му добу відійшла основна маса бджіл - 53,28\%. На 14-ту добу загальний відсоток гибелі склав 86,58\% бджіл. Фізіологічний стан бджіл - незадовільний, вони неактивні, злітали і падали. На 18-ту добу досліду прослідковувалась загибель 100\% бджіл.

У концентраціях препарату $0,15 \% ; 0,1 \% ; 0,03 \%$ та $0,01 \%$ у цукровому сиропі гострої токсичності на бджіл не відмічали. Натомість, за концентрацій $0,15 \%$ та $0,1 \%$ фізіологічний стан бджіл був задовільний, бджоли активні з підвищеним апетитом, порівняно 3 контролем, літали по садку.

Загибель бджіл протягом 21-го дня виражена у відсотках

Табличя 1

\begin{tabular}{|l|c|c|c|c|c|c|}
\hline День досліду & $0,3 \%$ & $0,15 \%$ & $0,1 \%$ & $0,03 \%$ & $0,01 \%$ & контроль \\
\hline $1-$ й & 3,33 & 0 & 0 & 0 & 0 & 0 \\
\hline $7-$ й & 53,28 & 9,99 & 13,32 & 9,99 & 6,66 & 13,32 \\
\hline $14-$ й & 86,58 & 33,3 & 23,31 & 16,65 & 23,31 & 23,31 \\
\hline $21-$ й & 100 & 39,96 & 39,96 & 53,28 & 59,94 & 53,28 \\
\hline
\end{tabular}

Перший падіж бджіл за концентрації 0,15\% відмічали на 6-й день досліду. До 7-ї доби загинуло 9,99\% бджіл. На 14-ту добу загинуло 33,3\% бджіл, на 21-у добу загальний відсоток загибелі склав 39, 96\%, залишилися живими 60,04\% бджіл і активно поїдали сироп. Тому при такій концентрації ми можемо говорити про активізуючу і стимулюючу дію препарату, наслідком чого $є$ продовжене життя бджіл.

Аналізуючи дані досліду 3 концентрацією $0,1 \%$ необхідно відмітити схожу картину з концентрацією 0,15\%. На 7-му добу відмітили загибель 13,32\% бджіл, на 14-ту добу загинуло 23,31 \% бджіл та на 21-у добу загальний відсоток загибелі склав 39,96\%. 60,04\% залишились живими, що свідчить про продо- вжене життя бджіл, як у попередньому випадку 3 концентрацією $0,15 \%$.

За концентрації 0,03\% на 7-му добу падіж бджіл склав 9,99\%, на 14-ту добу - 16,65\%. На 21-у добу досліду відмітили 53,28\% загибелі бджіл. При спостереженні за садком ми не відмічали пригніченого стану бджіл, але по садку бджоли не літали, малоактивні.

У садку з концентрацією препарату $0,01 \%$ на 7-му добу загинуло 13,32\%, на 14-ту добу відмічали загибель 23, 31\%, на 21-у добу загальний відсоток загибелі склав 59, 94\%. Живими залишилося 40,0 6\%. За час досліду бджоли були неактивні, злітали і падали.

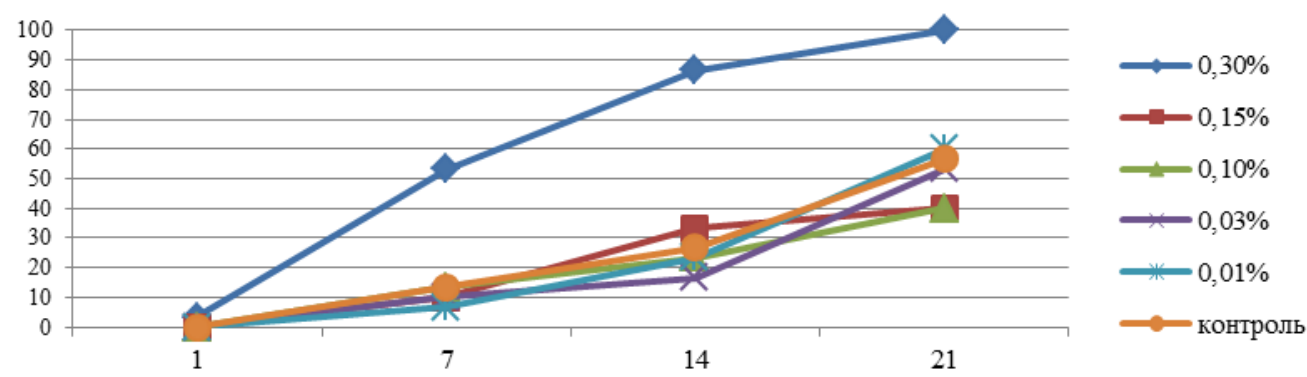

Рис. 2. Динаміка загибелі дослідних бджіл протягом 21 доби 
Аналізуючи дані рис. 2. Динаміка загибелі бджіл протягом 21 доби, необхідно відмітити, що гостру дію ми спостерігаємо за концентрації препарату $0,3 \%$.

\section{Висновки}

1. У концентрації препарату «Біоконтакт плюс» $0,3 \%$ в ізоляторах за контактної дії зареєстровано тимчасовий токсичний ефект протягом перших 6-ти діб, після чого відмічали падіж 25\% бджіл. За концентрацій $0,15 \%, 0,1 \%$ та $0,01 \%$ токсичної дії не проявлялося, що підтверджується збереженням рухливості та активності бджіл в дослідних садочках протягом15-ти діб. На 21-й день досліду в кожному ізоляторі відійшло по $25 \%$ бджіл.

2. Гостру токсичну дію відмічали у садку з концентрацією препарату «Біоконтакт плюс» $0,3 \%$ за пероральної дії на 4-ту добу відійшло $10 \%$ бджіл. У садках з концентраціями $0,15 \%, 0,1 \%, 0,03 \%$ та $0,01 \%$ гострої токсичності не відмічали.

3. Використання препарату «Біоконтакт плюс» у концентраціях $0,15 \%$ та $0,1 \%$ проявляє стимулюючу та активізуючу дії, наслідком чого $є$ продовжене життя бджіл, підвищений апетит, порівняно з контролем. Дані концентрації можна рекомендувати до використання у присутності бджіл.

4. Препарат у концентраціях $0,03 \%$ та $0,01 \%$ не виявляють стимулюючої дії. За таких концентрацій відмічали знижений апетит, порівняно 3 контролем, активізуючої дії препарату у таких концентраціях не виявлено.
Перспективи подальших досліджень. Встановлені концентрації та дози «Біоконтакт плюс» необхідно вивчити як дезінфектанта та стимулятора активності бджолиної сім'ї в присутності бджіл, а також вивчити можливість накопичення препарату в меді та стільниках.

\section{Бібліографічні посилання}

Galatjuk, O.E. (2010). Hvorobi bdzhil ta osnovi bdzhil'nictva: navch. Posibnik. 2-ge vid., vipravl. idopovn. Zhitomir: Polissja (in Ukrainian).

Gar, K.A. (1963). Metody ispytanija toksichnosti i jeffektivnosti insekticidov. M.: Sel'hozizdat (in Russian).

Meged', A.G., Polishhuk, V.P. (1990). M41 Pchelovodstvo: Uchebnik / Per. s ukr. R.D. Bargan, L. P. Nikitinoj. K.: Vyshhashk. Golovnoeizdvo (in Russian).

Osinceva, L.A. (2000). Ekotoksikologicheskaja harakteristika pesticidov. Pchelovodstvo. 4, 17 (in Russian).

Osinceva, L.A. (2000). Ekotoksikologicheskaja harakteristika pesticidov. Pchelovodstvo. 5, 14 (in Russian).

Abbot, W.S. (1925). A method of Computing the Effectiveness of an Insecticide. J. Econ. Entomol. 18, $265-267$.

Instrukcija shhodo vikoristannja «Biokontakt pljus»[elektronnij resurs]. - Rezhim dostupu: http://kronosagro.com.ua/preparati/biokontakt_plys/ (in Ukrainian).

Стаття надійила до редакиї 15.09.2016 